\title{
BIOLOGICAL AGE AND CHRONIC FATIGUE IN TELEPHONE OPERATORS: EFFECTS OF NIGHT WORIKS
}

\author{
Bobko N. A., Martynovskaya T. Yu., Gadayeva D. A.
}

\section{State Institution «Kundiiev Institute of Occupational Health of the National Academy of Medical Sciences of Ukraine», Kyiv}

Introduction. Working at computer monitors under high information and sensory loads against hypodynamia is a factor of the development of the chronic fatigue (CF), which increases under shift work, especially - under night shifts. A kind of integral indicator of the body functional state of a human could be her/his biological age (BA).

The aim of the study is to reveal the relationship between BA and CF in telephone operators working under shift schedule with night shifts and without night shifts, and the reflection of these characteristics in parameters of body functioning.

Materials and research methods. 59 women (30-55 years old, $\mathrm{M} \pm \mathrm{m}: 40,7 \pm 0,9)$, who worked according to schedules with night shifts, and 43 women (31-52 years old, $\mathrm{M} \pm \mathrm{m}: 42,4 \pm 0,8)$ - without night shifts. The BA was studied according to V. P. Voitenko, the CF - according to A. B. Leonova and I. V. Shishkina. Measured: arterial blood pressure, systolic and diastolic (BPS, BPD), heart rate (HR), static balancing (SB), body weight, a questionnaire was conducted. Hemodynamic indices, self-assessment health index (SHI), pathological index (PI), BA, proper biological age (PBA), aging rate (AR) and chronic fatigue index (CFI) were calculated. The duration of the needed sleep per day was recorded. The data were processed at $\mathrm{p}<0,05$.

Research results. The BA of telephone operators working on the schedules with night shifts was $(41,7 \pm 1,0)$ years, PBA $(40,9 \pm 0,5)$ years, AR $-(0,7 \pm 1,1)$ years. The BA of telephone operators working on the schedules without night shifts was $(42,8 \pm 1,3)$ years, PBA - $(41,9 \pm 0,5)$ years, AR $-(0,9 \pm 1,2)$ years. SHI $-(12,2 \pm 0,7)$ c. u. and $(12,6 \pm 0,8)$ c. u. for telephone operators of the first and second groups, respectively, PI - $(1,04 \pm 0,04) \mathrm{c}$. u. and $(1,08 \pm 0,05) \mathrm{c}$. u., SB $(25,8 \pm 2,3) \mathrm{s}$ and $(22,3 \pm 2,5) \mathrm{s}$. BPS, BPD and HR were $(126,2 \pm 2,0) \mathrm{mm} \mathrm{Hg} /(78,8 \pm 1,6) \mathrm{mm} \mathrm{Hg}$ and $(127,4 \pm 2,2) \mathrm{mm} \mathrm{Hg} /$ $(80,6 \pm 1,6) \mathrm{mm} \mathrm{Hg},(78,5 \pm 1,8) \mathrm{bpm}$ and $(75,2 \pm 1,6) \mathrm{bpm}$. Pulse pressure PP $-(47,4 \pm 1,3) \mathrm{mm} \mathrm{Hg}$ and $(46,8 \pm 1,3) \mathrm{mm} \mathrm{Hg}$ systolic volume $\mathrm{SV}-(52,0 \pm 1,3) \mathrm{ml}$ and $(49,6 \pm 1,2) \mathrm{ml}$, minute volume of blood flow MBV $-(4,1 \pm 0,1) 1$ and $(3,7 \pm 0,1) 1$, peripheral vascular resistance PVR - $(207,8 \pm 8,9) \mathrm{kPa} \cdot \mathrm{s} / \mathrm{l}$ and $(225,3 \pm 9,4) \mathrm{kPa} \cdot \mathrm{s} / \mathrm{l}$, Kerdo's vegetative index KVI $(-2,4 \pm 2,5)$ c. u. and $(-8,5 \pm 2,5)$ c. u., bloodcirculatory insufficiency index BII $-(1,64 \pm 0,03)$ c. u. and $(1,71 \pm 0,04)$ c. u. It was found $(19,4 \pm 2,4)$ points and $(21,2 \pm 2,3)$ points out of 72 possible on the CFI scale, with the greatest weight of three symptom groups: «physiological discomfort», «disturbances in the sleep-wake cycle», «decreased overall well-being and cognitive discomfort». The duration of the needed sleep was $(8,0 \pm 0,2) \mathrm{h}$ and $(8,2 \pm 0,1) \mathrm{h}$. The telephone operators working with night shifts showed twice as many correlations between BA and CFI ( $<<0,001)$. Sleep lengthening in those working with night shifts was associated with a decrease in BA and PP, in those working without night shifts - with a decrease in PP, mean dynamic pressure, and BII.

Conclusions. The BA of telephone operators practically corresponds to their calendar age and PBA, while AR - to the average population ratio. The functional state of the bloodcirculatory system, in general, is qualified at the level of the «middle class», however, the predominance of the parasympathetic system in the autonomic regulation of bloodcirculation and an increased BII were revealed. The initial degree of chronic fatigue development was found. For operators working on schedules with night shifts, the development of biological aging and chronic fatigue correlate twice as severe as for those working without night shifts $(\mathrm{p}<$ 0,001). An increase in the duration of sleep can serve to prevent the development of pathology of the bloodcirculatory system (especially for shiftworkers without night work hours), as well as a tool for «biological rejuvenation» - for night shiftworkers.

Key words: aging rate, shift work, bloodcirculatory system, static balancing, self-assessment of health, sleep

\section{Introduction}

Telephone operators are typical representatives of employees with a predominantly mental character of work at high information and sensory loads, working at video terminals of computers under shift schedule [1]. There are more and more occupations with simi- lar characteristics of working conditions in a modern society that is active « $24 / 7 »$, that actualizes physiological and hygienic studies of the functional body state of workers and the effects of factors of their working conditions.

Some integral indicator of the functional body state of a human could serve her/his biological age [2], 
reflecting the actual state of physiological systems and functions of the body. Biologically older people are those with poorer health conditions. People of accelerated aging form risk groups.

Working at video terminals of computers under high information and sensory loads against the background of hypodynamia is a factor of chronic fatigue development $[3,4]$ - an unfavorable functional body state, which, in turn, increases under shift work and concomitant systematic sleep pattern disturbances [5], and leads to health problems [3-5]. At the same time, shift work including night work hours violates the circadian body rhythms and sleep pattern to the greatest extent. However, the issues of the relationship between biological age, chronic fatigue and night work remain insufficiently studied.

The aim of the study is to reveal the relationship between biological age and chronic fatigue in telephone operators working under shift schedule with night shifts and without night shifts, and the reflection of these characteristics in parameters of body functioning.

\section{Materials and methods of the study}

Telephone operators of «Ukrtelecom» branches were examined at their workplaces - 102 women, who were familiarized with the purpose and objectives of the research and signed an informed consent to participate in the research. 59 women $(30-55$ years old, $M \pm \mathrm{m:}$ 40,7 $\pm 0,9$ ) worked according to shift schedules including night shifts (group 1), and 43 women (31-52 years old, $M \pm m: 42,4 \pm 0,8)$ - without night shifts (group 2). Under 36-hour working week, the shift schedules varied significantly, night shifts provided for the right to 2 -hour sleep, and there could be no more than three night shifts during a month.

According to the literature, telephone operators show the signs of overstrain and exhaustion of regulatory physiological systems, in particular, the inadequacy in the hemodynamic system reactions to the workload [1]. Therefore, the biological age was studied using the V. P. Voytenko's method (1991) [2], that is based on the parameters of the bloodcirculatory system functioning and health complaints, and at the same time is one of the most frequently used method. The following measurements were made: blood pressure, systolic and diastolic (BPS, BPD), heart rate (HR), static balancing ( $\mathrm{SB}$ ) due to Uemura's test (the duration of static balancing on the left leg), body weight (BW). A questionnaire survey was conducted. According to V. P. Voytenko's method, the following parameters were calculated: self-assessment health index (SHI) based on a questionnaire, pathological index (risk of chronic diseases) (PI $=0,011 \cdot \mathrm{A}+$ $0,057 \cdot \mathrm{SHI}-0,103$, where $\mathrm{A}$ is the calendar age); biological age $(\mathrm{BA}=-1,46+0,42 \cdot(\mathrm{BPS}-\mathrm{BPD})+$ $0,25 \cdot \mathrm{BW}+0,70 \cdot \mathrm{SHI}-0,14 \cdot \mathrm{SB})$; proper biological age $(\mathrm{PBA}=0,581 \cdot \mathrm{A}+17,3)$; aging rate $(\mathrm{AR}=\mathrm{BA}-\mathrm{PBA})[2]$.

To study the functional state of the bloodcirculatory system, the following parameters were calculated: pulse pressure $\mathrm{PP}=\mathrm{BPS}-\mathrm{BPD}$; mean dynamic pressure $\mathrm{MDP}=0,42 \cdot \mathrm{PP}+\mathrm{BPD}$; systolic blood volume $\mathrm{SV}=100+0,5(\mathrm{BPS}-\mathrm{BPD})-0,6 \cdot$ $\mathrm{BPD}-0,6 \cdot \mathrm{A}$ (where $\mathrm{A}$ is the calendar age); minute bloodflow volume $\mathrm{MBV}=\mathrm{SV} \cdot \mathrm{HR}$; peripheral vascular resistance $\mathrm{PVR}=(\mathrm{MDP} \cdot 1333 \cdot 60) / \mathrm{MBV}$; Kerdo's vegetative index KVI $=(1-\mathrm{BPD} / \mathrm{HR}) \cdot$ $100 \%$; bloodcirculatory insufficiency index BII = BPS/HR [6, 7].

The Chronic Fatigue Index (CFI) was assessed according to the method of A. B. Leonova and I. V. Shishkina (2003) [8]. Considering sleep is the most effective restoring resource of a body and also preventive measure regarding chronic fatigue development, the duration of the needed sleep per day (in hours) was recorded.

The data were processed using standard software packages for statistical data processing (Ms Excel 2007) using basic statistics, T-test, Pearson correlation analysis at the level of statistical significance $\mathrm{p}<$ 0,05 as reliable.

\section{Research results and their discussion}

The biological age of telephone operators working night shifts averaged $(41,7 \pm 1,0)$ years for the group, a proper biological age $-(40,9 \pm 0,5)$ years, the aging rate $-(0,7 \pm 1,1)$ years. The biological age of telephone operators working without night shifts was $(42,8 \pm 1,3)$ years, a proper biological age $-(41,9 \pm$ $0,5)$ years, the aging rate $-(0,9 \pm 1,2)$ years. The aging rate of telephone operators of the each group is classified as a mean population one [2] and does not differ significantly between the groups.

The self-assessment health index ( $\mathrm{SHI}$ ) averaged across groups was $(12,2 \pm 0,7)$ c. u. and $(12,6 \pm 0,8)$ c. u. among telephone operators of the first and second groups, respectively, which corresponds to the 
age norm of the observed subjects [9] and does not differ significantly between the groups.

The pathological index (PI) as a mean within the groups was $1,04 \pm 0,04$ and $1,08 \pm 0,05$ in the telephone operators of the first and second groups, respectively, and did not differ significantly between the groups.

Arterial blood pressure and pulse were within the physiological norm in the telephone operators of the each group: $(126,2 \pm 2,0) \mathrm{mm} \mathrm{Hg} /(78,8 \pm 1,6) \mathrm{mm} \mathrm{Hg}$ and $(127,4 \pm 2,2) \mathrm{mm} \mathrm{Hg} /(80,6 \pm 1,6) \mathrm{mm} \mathrm{Hg}$, $(78,5 \pm 1,8) \mathrm{bpm}$ and $(75,2 \pm 1,6 \mathrm{bpm}$ and do not differ significantly between the groups.

Static balancing (characterizing also the level of blood supply to the brain) within the group of telephone operators working due to schedules including night shifts was $(25,8 \pm 2,3)$ s, which corresponds to the age standard for 35 -year-olds (Table 1 , cited from [10]) - i. e. 5.7 years younger than the mean age of the observed subjects; within the group of telephone operators working without night shifts - $(22,3 \pm 2,5) \mathrm{s}$, which corresponds to the age standard for 38 -yearolds - i. e. 4,4 years younger than the mean age of the observed subjects.

The pulse pressure within the groups of telephone operators was $(47,4 \pm 1,3) \mathrm{mm} \mathrm{Hg}$ (group 1) and $(46,8 \pm 1,3) \mathrm{mm} \mathrm{Hg}$ (group 2), that corresponds to the age standard of the observed women [11]. The mean group levels of SV were $(52,0 \pm 1,3) \mathrm{ml}$ and $(49,6 \pm 1,2) \mathrm{ml}$, respectively, MBV $-(4,1 \pm 0,1) 1$ and $(3,7 \pm 0,1) 1, \mathrm{PVR}-(207,8 \pm 8,9) \mathrm{kPa} \cdot \mathrm{s} / \mathrm{l}$ and $(225,3 \pm 9,4) \mathrm{kPa} \cdot \mathrm{s} / 1$, that makes it possible to qualify the functional state of the bloodcirculatory system as a whole as corresponding to the «middle class», although the mean group PVR value in daytime telephone operators was found within the zone «below the middle class» [12]. KVI averaged for the groups was $(-2,4 \pm 2,5)$ c. u. and $(-8,5 \pm 2,5)$ c. u., respectively, that indicates the predominance of parasympathetic influences in the bloodcirculatory system regulation in the observed subjects [13]. BII was $(1,64 \pm 0,03)$ c. u. and $(1,71 \pm 0,04)$ c. u. - respectively, that may reflect an increase in tension in the efforts of regulatory mechanisms of the bloodcirculatory system [1] and a decrease in the quality of func- tioning of the peripheral vascular bed as a result of hypodynamia [14]. No significant differences were found between the groups, however, in all cases, the worst indicators at the level of trends were found among the daytime telephone operators, which may reflect both the result of elemental occupational selection (people with a relatively better state of health go to work at night shifts), and the influence of other accompanying unaccounted factors.

According to the average group data, the telephone operators amounted $(19,4 \pm 2,4)$ points (group 1) and $(21,2 \pm 2,3)$ points (group 2 ) out of 72 possible on the CFI scale, that is qualified as the initial stage of chronic fatigue development [8]. Among the five groups of symptoms, CFI's components, the greatest weight belongs to three symptom groups - of «physiological discomfort», signs of «disturbances in the sleep-wake cycle», «decreased overall well-being and cognitive discomfort» (Figure), that indicates a greater depth of psychological disorders and somatizing the negative effects of chronic fatigue in the area of the respective symptoms compared to the other two symptom groups. The differences between the two groups of subjects are statistically insignificant for each symptom group, however, among telephone operators working on schedules with night shifts, each of these three groups of symptoms makes a significantly more important contribution to the CFI development compared to the fifth symptom - «decreased motivation and changes in social communication» $(p<0,03)$. In telephone operators working on schedules without night shifts, the symptom group «emotional-affective disorders» contributed at the level of the first three groups of symptoms, and significantly exceeded the contribution of the symptom group «decreased motivation and changes in social communication» $(p<0,003)$.

The duration of the needed sleep was $(8,0 \pm 0,2) \mathrm{h}$ and $(8,2 \pm 0,1) \mathrm{h}$ in the two groups, respectively, and did not differ significantly.

Between parameters that form biological age and parameters that form chronic fatigue, telephone operators working on shift schedules with night shifts were found to have two times more reliable correlations compared to telephone operators working on shift schedules without night shifts ( $\mathrm{p}<0,001)$ (Table 2$)$.

Age standards for static balancing (cited from [10])

\begin{tabular}{|l|l|l|l|l|l|l|l|l|l|}
\hline Age, years & 20 & 30 & 35 & 40 & 45 & 50 & 55 & 60 & 65 \\
\hline Duration of static balancing, s & 40 & 30 & 25 & 20 & 17 & 15 & 12 & 10 & 8 \\
\hline
\end{tabular}




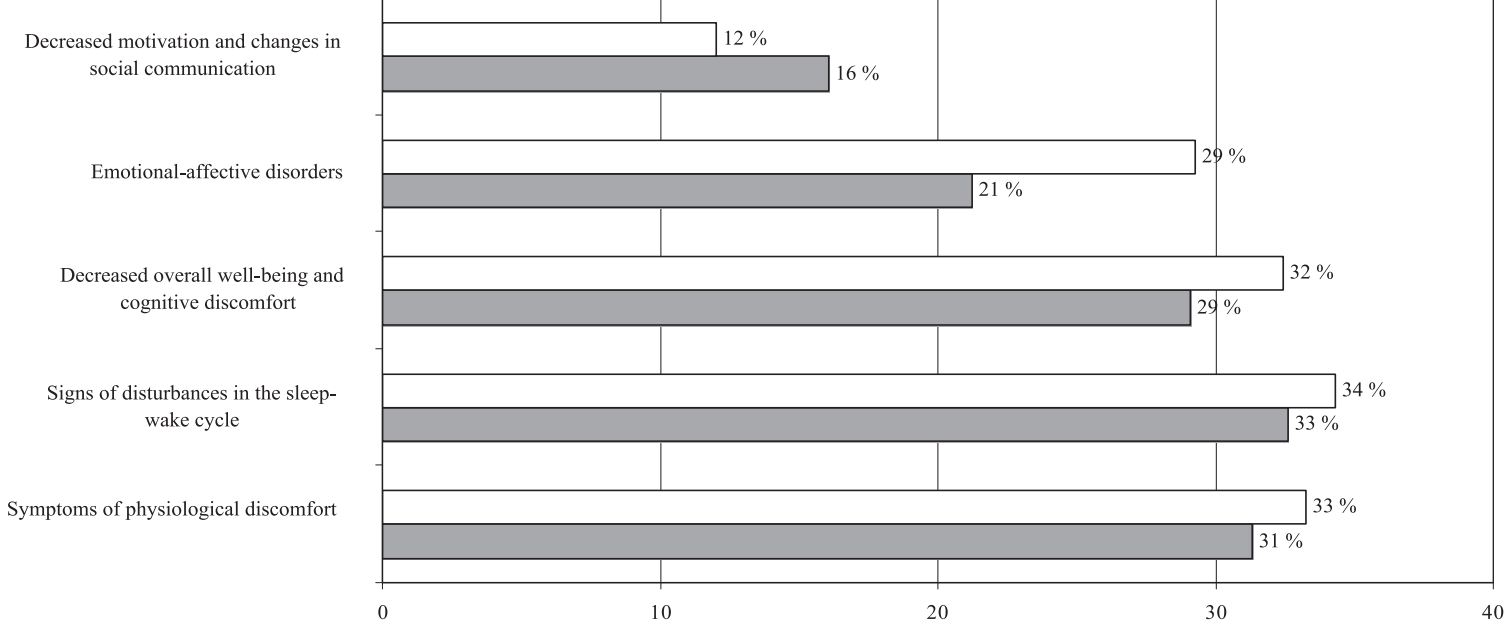

Figure. The severity of symptom groups that form the index of chronic fatigue in telephone operators

$X$ axis - the severity of the symptom's group in relation to the maximum possible number of its manifestations (in percent).

Y axis - symptom groups.

Grey bars - data of operators working on shift schedules including night shifts, white bars - data of operators working on shift schedules without night shifts. Differences between groups are not statistically significant for each symptom group.

At the same time, with an increase in biological age, the rate of aging, SHI and PI, the severity of chronic fatigue (values of the CFI) and the symptoms of its components increased in both groups, but in the group of people working with night shifts, there were more such reliable pairs of correlations $(p<0,05)$. They also showed a significant increase in the severity of chronic fatigue and/or its symptoms with a decrease in a score of number of objective parameters - BPS, $\mathrm{BPD}, \mathrm{MDP}$ and SB - in contrast to telephone operators working on schedules without night shifts.

An increase in the duration of sleep in those working with night shifts was associated with a decrease in biological age and pulse pressure, in those working without night shifts - with a decrease in PP, MDP and BII.

Thus, according to the mean group data, it was revealed that the biological age of telephone operators practically corresponds to the calendar and proper biological age (deviations of the mean values are within one year), and the rate of their aging is qualified as the average population level. The self-assessment health index (SHI), on average for the groups, corresponds to the age norm of the observed subjects. The level of blood supply to the brain in telephone operators corresponds to a younger age - by $4-6$ years, and this fact requires further research. In general, the state of the bloodcirculatory system is at the level of the «middle class», however, the predominance of the parasympathetic nervous system in the autonomic regulation of bloodcirculation (which in the literature is associated with an increase in stress and a decrease in the adaptive reserves of physiological systems [15-17]) and an increased index of bloodcirculation insufficiency were found, that may be the result of intense mental work against the background of physical inactivity, the shift regime of work and other unfavourable factors of working and living conditions.

The initial degree of chronic fatigue development in telephone operators of both groups was revealed at the leading role of three symptom groups - «physiological discomfort», «disturbances in the sleep-wake cycle», «decreased overall well-being and cognitive discomfort». The telephone operators who work without night shifts also have a fourth symptom group «emotional-affective disorders».

The influence of night works on the mean levels of the studied parameters is not significant, that may be a consequence of the relatively small number of night shifts in the observed contingent (no more than 3 per month) and also the presence of other concomitant factors affecting these parameters. For example, the workplaces of the telephone operators were equipped with monitors of various types, whilst work at monitors such as a cathoderay tube is accompanied by an acceleration in the aging rate by 3 years compared to work at liquid crystal screens [18], and therefore this factor can act as an incidental.

At the same time, statistically significant differences in the mechanisms of the development of functional body states were revealed: in people working on schedules with night shifts, there are significantly 
Table 2

Correlation $(\mathrm{p}<0,05)$ of parameters that form biological age and chronic fatigue in telephone operators working on schedules with night shifts and without night shifts

\begin{tabular}{|c|c|c|c|c|c|c|c|c|c|c|}
\hline & BA & $\mathbf{A R}$ & SHI & PI & BPS & BPD & PP & MDP & BII & SB \\
\hline \multicolumn{11}{|l|}{ Schedules with night shifts: } \\
\hline CFI & 0,38 & 0,37 & 0,83 & 0,81 & $-0,32$ & - & - & $-0,29$ & - & $-0,41$ \\
\hline Symptoms of physiological discomfort & 0,37 & 0,35 & 0,82 & 0,80 & $-0,39$ & $-0,31$ & - & $-0,36$ & - & $-0,39$ \\
\hline Signs of disturbances in the sleep-wake cycle & 0,32 & 0,34 & 0,71 & 0,68 & $-0,29$ & - & - & - & - & $-0,31$ \\
\hline Decreased overall well-being and cognitive discomfort & 0,34 & 0,33 & 0,75 & 0,74 & - & - & - & - & - & $-0,46$ \\
\hline Emotional-affective disorders & 0,28 & - & 0,70 & 0,69 & $-0,28$ & - & - & - & - & $-0,20$ \\
\hline $\begin{array}{l}\text { Decreased motivation and changes in social com- } \\
\text { munication }\end{array}$ & 0,37 & 0,43 & 0,59 & 0,54 & - & - & - & - & - & $-0,29$ \\
\hline Duration of the needed sleep & $-0,33$ & - & - & - & - & - & $-0,34$ & - & - & - \\
\hline \multicolumn{11}{|l|}{ Schedules without night shifts: } \\
\hline CFI & 0,40 & 0,50 & 0,77 & 0,71 & - & - & - & - & - & - \\
\hline Symptoms of physiological discomfort & 0,40 & 0,46 & 0,74 & 0,69 & - & - & - & - & - & - \\
\hline Signs of disturbances in the sleep-wake cycle & - & 0,34 & 0,58 & 0,53 & - & - & - & - & - & - \\
\hline Decreased overall well-being and cognitive discomfort & 0,35 & 0,44 & 0,74 & 0,68 & - & - & - & - & - & - \\
\hline Emotional-affective disorders & - & 0,42 & 0,51 & 0,45 & - & - & - & - & - & - \\
\hline $\begin{array}{l}\text { Decreased motivation and changes in social } \\
\text { communication }\end{array}$ & - & - & - & - & - & - & - & - & - & - \\
\hline Duration of the needed sleep & - & - & - & - & - & - & $-0,51$ & $-0,37$ & $-0,40$ & - \\
\hline
\end{tabular}

more rigid connections between the physiological mechanisms of aging (including parameters of blood circulation and blood supply to the brain) and symptoms that form chronic fatigue, compared to those who work in the daytime only.

An analysis of the duration of adequate sleep - the natural mechanism of the body's recovery - showed fundamentally different ways of recovery: for people working at night shifts, an increase in the duration of sleep becomes a tool for reducing biological age («biological rejuvenation»), while for people who work only in the daytime hours - a way to reduce the mean dynamic pressure and the bloodcirculatory insufficient index. For both groups, an increase in the duration of sleep is associated with a decrease in pulse pressure, that can be considered as a prevention tool of the development of hypertension [19].

\section{Conclusions}

1. The biological age of telephone operators, on average, practically corresponds to their calendar and proper biological age (deviations of mean values are within one year), the aging rate of operators is $(0,7 \pm 1,1)$ years and $(0,9 \pm 1,2)$ years (for those working on schedules with and without night shifts, respectively) and qualifies as a mean-population aging rate. The self-assessment health index, as a mean for the groups, corresponds to the age norm of the examined subjects, the level of blood supply to the brain - to the age $4-6$ years younger.

2. The functional state of the bloodcirculatory system of telephone operators, in general, is qualified at the level of the «middle class», however, the predominance of the parasympathetic branch of the nervous system in the autonomic regulation of bloodcirculation and an increased index of bloodcirculatory insufficiency, that is associated in the literature with an increase in stress and a decrease in adaptive reserves of physiological systems, and may be the result of intense mental work against the background of physical inactivity, the shift character of work and unfavorable levels of other factors of working conditions.

3. The initial degree of chronic fatigue was revealed in telephone operators with the leading role of three symptom groups - «physiological discomfort», 
«disturbances in the sleep-wake cycle», «decreased overall well-being and cognitive discomfort», for those who work only during the daytime, also the fourth symptom group - «emotional-affective disorders $\gg$.

4. For telephone operators working on the schedules with night shifts, the development of biological aging and chronic fatigue is connected twice as severe as for those working without night shifts $(p<0,001)$. With an increase in biological age, rate of aging, index of self-assessment of health and pathological index, the severity of chronic fatigue increased in both observed operator groups; in the group of people working with night shifts, there were more such significant pairs of correlations $(p<0,05)$. In them, the severity of chronic fatigue significantly increased with a decrease in systolic, diastolic, mean dynamic pressure and static

\section{References}

1. Tebenova K. S., Ilyasova B. I., Zarkenova Zh. T. and Zarkenova, L. S. (2015), «Functional state of the bloodcirculatory system in employees of video display terminals in shift dynamics», Uspekhi sovremennogo yestestuoznaniya, 1, 382-387.

2. Voytenko V. P. (1991), Zdorov'ye zdorovykh [Health of the healthy]. Kyiv : Zdorov'ya.

3. Tebenova K. S. (2011), «To a question on the formation of processes of fatigue and overfatigue when working with videodisplay terminals», Gigiyena truda $i$ meditsinskaya ekologiya, 2 (31), 20-33.

4. Navakatikyan A. O. (1986), «Chronic mental fatigue and overfatigue», Gigiyena truda, 22, 7-15.

5. Longman D. P., Shaw C. N., Varela-Mato V. et al. (2021), «Time in Nature Associated with Decreased Fatigue in UK Truck Drivers», Int J Environ Res Public Health, 18 (6), 3158. https://doi.org/10.3390/ ijerph 18063158.

6. Arinchin N. I., Kulago G. F. (1969), Gipertonicheskaya bolezn' kak narusheniye samoregulyatsii krovoobrashcheniya [Hypertensive disease as a violation of blood circulation self-regulation], Minsk: Science and technology.

7. Khramov Yu. A., Veber V. R. (1985), Vegetativnoye obespecheniye i gemodinamika pri gipertonicheskoy bolezni [Vegetative support and hemodynamics in hypertension], Novosibirsk: Nauka.

8. Spartakova A. S., Leonova A. B. (2016), «Methodology "The degree of chronic fatigue"», Psikholo- balancing $(\mathrm{p}<0,05)$ - in contrast to telephone operators working on schedules without night shifts, in whom reliable relationships between these indicators were not found.

5. An increase in the duration of everyday sleep in telephone operators is accompanied by a decrease in pulse pressure $(p<0,05)$. In those who work only in the daytime hours, the mean dynamic pressure and the index of bloodcirculatory insufficiency also decrease $(p<0,05)$. Among those working also at night, the biological age decreases $(p<0,05)$. Consequently, an increase in the duration of sleep can serve the purposes of preventing the development of pathology in the bloodcirculatory system (especially for shiftworkers without night work hours), as well as a tool of «biological rejuvenation» - for night shiftworkers.

gicheskiye tekhnologii upravleniya sostoyaniyem cheloveka [Psychological technologies for managing the state of a person]. URL: https://netrefs.ru/alla-spartakovna-kuznecova-anna-borisovna-leonova-psihologiche.html?page $=17$.

9. Boyko A. (2003), Zdorovyye testy [Healthy tests], Moscow : Rossiyskaya Gazeta. ISBN: 5-94829-008-5. URL: http://www.libex.ru/detail/book856988.html.

10. Staticheskaya balansirovka. Vozrastnyye normativy [Static balancing. Age standards]. URL: http://beautyaura.ru/articles/health/staticheskaya-balansirovka/.

11. Chto eto - pul'sovoye davleniye [What is it pulse pressure]. URL: https://gb3str.ru/zabolevaniya/ pulsovoe-davlenie - chto - eto - norma - po-vozrastamtablitsa-chto-otobrazhaet.html.

12. Buzunov V. A. (1991), Proizvodstvennye faktory i vozrastnaya rabotosposobnost', [Production factors and age performance]. Kiev : Zdorov'ya, Ukraine.

13. Kérdö I.( 1966), Ein aus Daten der Blutzirkulation kalkulierter Index zur Beurteilung der vegetativen Tonuslage von I. Kérdö. Acta neurovegetativa, 29 (2), 250-268. https://doi.org/10.1007/BF01269900.

14. Boyarkina A. A. (2018), «Analysis of the tension of the bloodcirculatory system during prolonged work on the computer in students of different health groups», Sovremennyye tekhnologii v fizicheskom vospitanii i sporte [Modern technologies in physical education and sports], Materials of the All-Russian Scientific and Practical Conference with International Participation, Tula, 23-24 November 2018, Ed. A. Yu. Frolov, 
245-247. URL: https://elibrary.ru/download/elibrary_36537969_22447183.pdf.

15. Vorona A. A., Golovkina O. L., Matyukhin V. V., Yushkova O. I. (1999), «Influence of occupational factors on the clinical and physiological status of persons working with video display terminals», Meditsina truda i prom. ekologiya, 7, 25-28.

16. Tkachenko L. M., Perederiy H. S. (2000), «Vegetative correlates of emotional stress in persons with different states of the autonomic nervous system», Fiziolohichnyy zhurn, 46 (6), 61-67.

17. Sato S., Taoda K., Kawamura M. et al. (2001), «Heart rate variability during long truck driving work». J. Hum. Ergol. 30 (1-2), 235-240.
18. Nazarenko V. I., Chebanova O. V., Martirosova V. G., Karakashyan A. N., Martynovska, T. Y. et al. (2007), «Physiological and hygienic assessment of working conditions telephone operators modern digital communication», Ukrainian Jornal of Occupational Health, 3, 49-56. https://doi. org/10.33573/ujoh2007.03.049.

19. Orayeva B. N., Atayev O. G., Korotenko T. I. (2015), «Pulse pressure as a predictor of the development of hypertension», Nauchnyy rezul'tat. Seriya Meditsina $i$ farmatsiya [Research Result. Medicine and Pharmacy Series], 1 (3), 50-54. https://doi.org/ 10.18413/2313-8955-2015-1-3-50-54.

\section{Бобко Н. А., Мартиновсыка Т. Ю., Гадаева А. О.

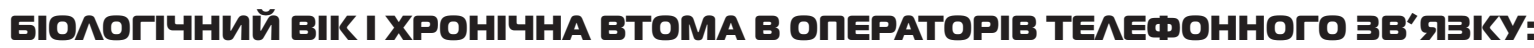 впヘИв НІЧнИХ РОБІт}

\section{Аержавна установа «Інститут медицини праші імені Ю. І. Кундієва Націона^ьної академії медичних наук України», м. Київ}

Bcmyn. Робота за моніторами комп'ютерів з високими інформаційними та сенсорними навантаженнями на тлі гіподинамії є чинником формування хронічної втоми, яка посилюється при змінній праці, особливо - із нічними змінами. Деяким інтегральним показником функціонального стану людини може слугувати їі біологічний вік.

Мета дослідження - виявити зв'язок біологічного віку та хронічної втоми в операторів телефонного зв'язку, що працюють у змінному режимі з нічними змінами і без нічних змін, і відображення цих характеристик у показниках функціонування організму.

Матеріали та методи дослідження. Обстежено 59 жінок (30-55 років, M \pm m: 40,7 \pm 0,9), які працювали за графіками з нічними змінами, і 43 жінки (31-52 років, $\mathrm{M} \pm \mathrm{m}: 42,4 \pm 0,8)$ - без нічних змін. Вивчали біологічний вік (БВ) за В. П. Войтенком та хронічну втому за А. Б. Леоновою і І. В. Шишкіною. Вимірювали артеріальний тиск систолічний (АТС) і артеріальний тиск діастолічний (АТД), частоту серцевих скорочень (ЧСС), статичне балансування (СБ), масу тіла, проводили анкетування. Розраховували показники гемодинаміки, індекс самооцінки здоров'я (СО3), патологічний індекс (ПІ), БВ, належний біологічний вік (НБВ), темп старіння (ТС), індекс хронічної втоми (ІХРВ). Реєстрували тривалість необхідного сну на добу. Дані обробляли на рівні $\mathrm{p}<0,05$.

Результати. БВ телефоністок, які працюють за графіками з нічними змінами, склав $(41,7 \pm 1,0)$ років, НБВ $(40,9 \pm 0,5)$ років, ТС $-(0,7 \pm 1,1)$ року. БВ телефоністок, які працюють за графіками без нічних змін, склав $(42,8 \pm 1,3)$ років, НБВ $-(41,9 \pm 0,5)$ років, ТС $-(0,9 \pm 1,2)$ року. Показник СО3 склав $(12,2 \pm 0,7)$ у. о. і $(12,6 \pm$ $0,8)$ у. о. у телефоністок першої та другої групи відповідно, ПІ - $(1,04 \pm 0,04)$ у. о. і $(1,08 \pm 0,05)$ у. о., СБ - $(25,8 \pm$ $2,3)$ с і $(22,3 \pm 2,5)$ с. Показники АТС, АТД і ЧСС склали $(126,2 \pm 2,0)$ мм рт. ст. $/(78,8 \pm 1,6)$ мм рт. ст. і $(127,4 \pm$ $2,2)$ мм рт. ст. $/(80,6 \pm 1,6)$ мм рт. ст., $(78,5 \pm 1,8)$ уд./хв і $(75,2 \pm 1,6)$ уд./хв. Пульсовий тиск $(П Т)$ склав $(47,4 \pm$ $1,3)$ мм рт. ст. і $(46,8 \pm 1,3)$ мм рт. ст., систолічний об'єм $(\mathrm{CO})-(52,0 \pm 1,3)$ мл і $(49,6 \pm 1,2)$ мл, хвилинний об’єм кровотоку $(\mathrm{XOK})-(4,1 \pm 0,1)$ л і $(3,7 \pm 0,1)$ л, периферичний опір судин (ПОС) - $(207,8 \pm 8,9)$ кПа • с/л і $(225,3 \pm$ $9,4)$ кПа • с/л, вегетативний індекс Кердо (ВIK) - (-2,4 $\pm 2,5)$ у. о. і $(-8,5 \pm 2,5)$ у. о., індекс недостатності кровообігу (ІНК) - (1,64 $\pm 0,03)$ у. о. і $1,71 \pm 0,04$ у. о. Виявлено $(19,4 \pm 2,4)$ бала і $(21,2 \pm 2,3)$ бала з 72 можливих за шкалою IXPB, при найвагоміших трьох групах симптомів: «фізіологічний дискомфорт», «порушенння в циклі «сон - “неспання»"», «зниження загального самопочуття і когнітивний дискомфорт». Тривалість необхідного сну склала $(8,0 \pm 0,2)$ год і $(8,2 \pm 0,1)$ год. У телефоністок, які працюють за графіками з нічними змінами, виявлено вдвічі більше кореляційних зв'язків між БВ і IXPB (p <0,001). Подовження сну в працюючих за графіками з нічними змінами було пов’язане зі зниженням БВ і ПТ, у працюючих без нічних змін - зі зниженням ПТ, середньодинамічного тиску та ІНК.

Висновки. БВ операторів телефонного зв'язку практично відповідає їхньому календарному віку та НБВ, ТС середньопопуляційному. Функціональний стан системи кровообігу, в цілому, кваліфікується на рівні «середнього класу», однак виявлено переважання парасимпатичної системи у вегетативній регуляції кровообігу та підвищений ІНК. Виявлено початковий ступінь розвитку хронічної втоми. У операторів, що працюють за графіками з нічними 
змінами, розвиток біологічного старіння й хронічної втоми пов'язані вдвічі сильніше, ніж у працюючих без нічних змін ( $<$ 0,001). Збільшення тривалості сну може служити цілям профілактики розвитку патології системи кровообігу (особливо - для осіб змінної праці без нічних годин роботи), а також - інструментом «біологічного омолодження» для працюючих за графіками з нічними змінами.

Ключові слова: темп старіння, змінна праця, система кровообігу, статичне балансування, самооцінка здоров'я, сон

\title{
Бобко Н. А., Мартыновская Т. Ю., Гамаева А. А. БИОЛОГИЧЕСКИЙ ВОВРАСТ И ХРОНИЧЕСКОЕ УТОМАЕНИЕ У ОПЕРАТОРОВ ТЕАЕФОННОЙ СВЯЗИ: ВАИЯНИЕ НОЧНЫХ РАБОТ
}

\author{
Государственное учрежАение «Институт медицины труда имени Ю. И. Кундиева \\ Нашиональной академии медишинских наук Украины», г. Киев
}

Вступление. Работа за мониторами компьютеров с высокими информационными и сенсорными нагрузками на фоне гиподинамии является фактором формирования хронического утомления, которое усиливается при сменном труде, особенно - с ночными сменами. Некоторым интегральным показателем функционального состояния человека может служить его биологический возраст.

Цель исследования - выявить связь биологического возраста и хронического утомления у операторов телефонной связи, работающих в сменном режиме с ночными сменами и без ночных смен, и отражение этих характеристик в показателях функционирования организма.

Материалы и методы исследования. Обследовали 59 женщин (30-55 лет, M \pm m: 40,7 \pm 0,9), которые работали по графикам с ночными сменами, и 43 женщины (31-52 лет, M \pm m: 42,4 \pm 0,8) - без ночных смен. Изучали биологический возраст (БВ) по В. П. Войтенко и хроническое утомление - по А. Б. Леоновой и И. В. Шишкиной. Измеряли артериальное давление систолическое (АДС) и артериальное давление диастолическое (АДД), частоту сердечных сокращений (ЧСС), статическую балансировку (СБ), масу тела, проводили анкетирование. Рассчитывали показатели гемодинамики, индекс самооценки здоровья (СО3), патологический индекс (ПИ), БВ, должный биологический возраст (ДБВ), темп старения (ТС) и индекс хронического утомления (ИХРУ). Регистрировали длительность необходимого сна в сутки. Данные обрабатывали на уровне $\mathrm{p}<0,05$.

Результаты. БВ телефонисток, работающих по графикам с ночными сменами, составил $(41,7 \pm 1,0)$ лет, ДБВ $(40,9 \pm 0,5)$ лет, ТС $-(0,7 \pm 1,1)$ лет. БВ телефонисток, работающих по графикам без ночных смен, составил $(42,8 \pm$ $1,3)$ лет, ДБВ - $(41,9 \pm 0,5)$ лет, ТС - $(0,9 \pm 1,2)$ лет. Показатель СОЗ составил $(12,2 \pm 0,7)$ у. е. и $(12,6 \pm 0,8)$ у.е. у телефонисток первой и второй группы соответственно, ПИ - $(1,04 \pm 0,04)$ у. е. и $(1,08 \pm 0,05)$ у. е., СБ - $(25,8 \pm 2,3)$ с и $(22,3 \pm 2,5)$ с. АДС, АДД и ЧСС составили $(126,2 \pm 2,0)$ мм рт. ст./(78,8 $\pm 1,6)$ мм рт. ст. и $(127,4 \pm 2,2)$ мм рт. ст./ $(80,6 \pm 1,6)$ мм рт. ст., $(78,5 \pm 1,8)$ уд./мин и $(75,2 \pm 1,6)$ уд./мин. Пульсовое давление $(П Д)-(47,4 \pm 1,3)$ мм рт. ст. и $(46,8 \pm 1,3)$ мм рт. ст., систолический объем $(\mathrm{CO})-(52,0 \pm 1,3)$ мл и $(49,6 \pm 1,2)$ мл, минутный объем кровотока $(\mathrm{MOK})-(4,1 \pm 0,1)$ л и $(3,7 \pm 0,1)$ л, периферическое сопротивление сосудов $($ ПСС) $-(207,8 \pm 8,9) \mathrm{kПа} \cdot \mathrm{c} / л$ и $(225,3 \pm 9,4)$ кПа • с/л, вегетативный индекс Кердо (ВИК) - $(-2,4 \pm 2,5)$ у. е. и $(-8,5 \pm 2,5)$ у. е., индекс недостаточности кровообращения $($ ИНК $)-(1,64 \pm 0,03)$ у. е. и $(1,71 \pm 0,04)$ у. е. Выявлено $(19,4 \pm 2,4)$ балла и $(21,2 \pm 2,3)$ балла из 72 возможных по шкале ИХРУ, при наиболее весомых трех группах симптомов: «физиологический дискомфорт», «нарушения в цикле “сон - бодрствование”», «снижение общего самочувствия и когнитивный дискомфорт». Длительность необходимого сна составила $(8,0 \pm 0,2)$ ч и $(8,2 \pm 0,1)$ ч. У телефонисток, работающих по графикам с ночными сменами, выявлено вдвое больше корреляционных связей между БВ и ИХРУ (р < 0,001). Удлинение сна у работающих по графикам с ночными сменами было связано со снижением БВ и ПД, у работающих без ночных смен - со снижением ПД, среднединамического давления и ИНК.

Bыводы. БВ операторов телефонной связи практически соответствует их календарному возрасту и ДБВ, ТС среднепопуляционному. Функциональное состояние системы кровообращения, в целом, квалифицируется на уровне «среднего класса», однако выявлено преобладание парасимпатического отдела в вегетативной регуляции кровообрашения и повышенный ИНК. Выявлена начальная степень развития хронического утомления. У операторов, работающих по графикам с ночными сменами, развитие биологического старения и хронического утомления связаны вдвое сильнее, чем у работающих без ночных смен (p < 0,001). Увеличение длительности ежедневного сна может служить целям профилактики развития патологии системы кровообращения (особенно - для лиц сменного труда без ночных часов работы), а также - инструментом «биологического омоложения» для работающих по графикам с ночными сменами.

Ключевые слова: темп старения, сменный труд, система кровообращения, статическая балансировка, самооценка здоровья, сон 
ISSN 2223-6775, Ukrainian Journal of Occupational Health, 2021, 17(2), 93-101

ORCID співавторів та їхній внесок у підготовку та написання статті:

Бобко H. A. (ORCID 0000-0002-4545-7421) - постановка завдання, огляд літератури, аналіз даних, дизайн та написання тексту статті, підготовка ілюстративного матеріалу, формулювання висновків;

Мартиновська Т. Ю. (ORCID 0000-0002-9780-4341) - збір первинного матеріалу, підготовки бази даних, аналіз літератури, математико-статистична обробка даних;

Гадаєва Д. О. (ORCID 0000-0001-7493-6723) - пошук джерел літератури, підготовка бази даних, математикостатистична обробка даних.

Інформація щодо джерел фінансування дослідження: дослідження виконано за темою «Особливості вікових змін функціонального стану людини при нестандартних режимах роботи», № держреєстрації 0119U100585.

Надійшла: 7 травня 2021 р.

Прийнята до друку: 14 травня 2021 р.

Контактна особа: Бобко Наталія Андріївна, доктор біологічних наук, лабораторія гігієни та фізіології змінної праці, ДУ «Інститут медицини праці імені Ю. І. Кундієва НАМНУ», буд. 75, вул. Саксаганського, м. Київ, 01033. Тел.: + 3804428946 05. Електронна пошта: nbobko@bigmir.net 